\title{
Sunitinib induced immune thrombocytopenia in patient with metastatic renal cell carcinoma
}

\author{
Mutahir A. Tunio, Shoaib Ahmad, Mohsin Fareed, Mushabbab AlAsiri
}

Sindh Institute of Urology \& Transplantation (SIUT)-7400, Karachi, Pakistan

Corresponding author: Mutahir A. Tunio, MBBS, FCPS (Radiotherapy), Assistant Consultant, Radiation Oncology, Comprehensive Cancer Center, King Fahad Medical City (KFMC), Riyadh-59046, Saudi Arabia. Tel: +966 1 2889999, Fax: +966 14614006 E-mail: drmutahirtonio@hotmail.com.

\section{Abstract:}

Sunitinib (Sutent ${ }^{\circledR}$ : Pfizer, New York, NY, USA) is an oral multi-targeted tyrosine kinase inhibitor approved for firstline treatment of metastatic renal cell carcinoma (mRCC) and imatinib-resistant metastatic gastrointestinal stromal tumors (GIST). Common non hematological side effects secondary to sunitinib are: fatigue (74\%), diarrhea (55\%), nausea $(54 \%)$, altered taste $(43 \%)$, skin rash $(40 \%)$, hand foot syndrome $(30 \%)$ and hypertension $(28 \%)$. Common hematological side effects are neutropenia (53\%) and thrombocytopenia (38\%) secondary to myelosuppression. Here-in, we present case report of patient with inoperable metastatic left renal cell carcinoma who developed immune-mediated thrombocytopenia secondary to sunitinib and recovered successfully after sunitinib withdrawal. Differnetial diagnosis of drug induced immune mediated thrombocytopenia secondary to sunitinib must be made by oncologists in patients on sunitinib presenting as thrombocytopenia and in these cases sunitinib can safely be withdrawn.

\section{Key words:}

Metastatic renal cell carcinoma; Sunitinib; Immune-mediated thrombocytopenia

\section{NTRODUCTI ON}

The oral, multi-targeted tyrosine kinase inhibitor sunitinib (sunitinib malate; Sutent ${ }^{\mathbb{}}$; Pfizer Pharmaceuticals, New York) is known to inhibit vascular endothelial growth factor receptors (VEGFRs) 1, 2, and 3, platelet-derived growth factor receptor (PDGFR) $\alpha$ and $\beta$, KIT, Fms-like tyrosine kinase 3 receptor (FLT3), and the receptor encoded by the ret protooncogene (RET). ${ }^{1}$ Sunitinib is approved for first-line treatment of metastatic renal cell carcinoma (mRCC) and imatinibresistant metastatic gastrointestinal stromal tumors (GIST). ${ }^{2,3}$

Although generally associated with acceptable toxicity, sunitinib exhibits the common side effects: fatigue, diarrhea, anorexia, oral changes, hand-foot syndrome and other skin toxicity, thyroid dysfunction, thrombocytopenia secondary to 
myelosuppression and hypertension. ${ }^{4}$ However drug-induced immune thrombocytopenia (DIIT) secondary to sunitinib is extremely rare with only one case report has been in literature to date. ${ }^{5}$

Here in, we present a case of DIIT secondary to sunitinib in a man treated for inoperable metastatic renal cell carcinoma $(\mathrm{mRCC})$.

\section{CASE PRESENTATI ON}

A 46 years old man with no co morbidities, presented with 3 months history of gross hematuria and abdominal palpable mass. On general physical examination, the patient was malnourished, with fixed left lumbar mass with ill defined borders on palplation of abdomen. Baseline investigation including full blood count, urea and electrolytes, liver function tests and chest X-ray were normal. Abdominal computed tomography (CT) scan with intravenous contrast imaging demonstrated an approximately $12 \times 7.5 \times 5 \mathrm{~cm}$ sized solid mass in the left kidney with gross para-aortic lymphadenopathy. CT chest showed multiple pulmonary metastases (Figure 1). Bone scan of patient was negative.

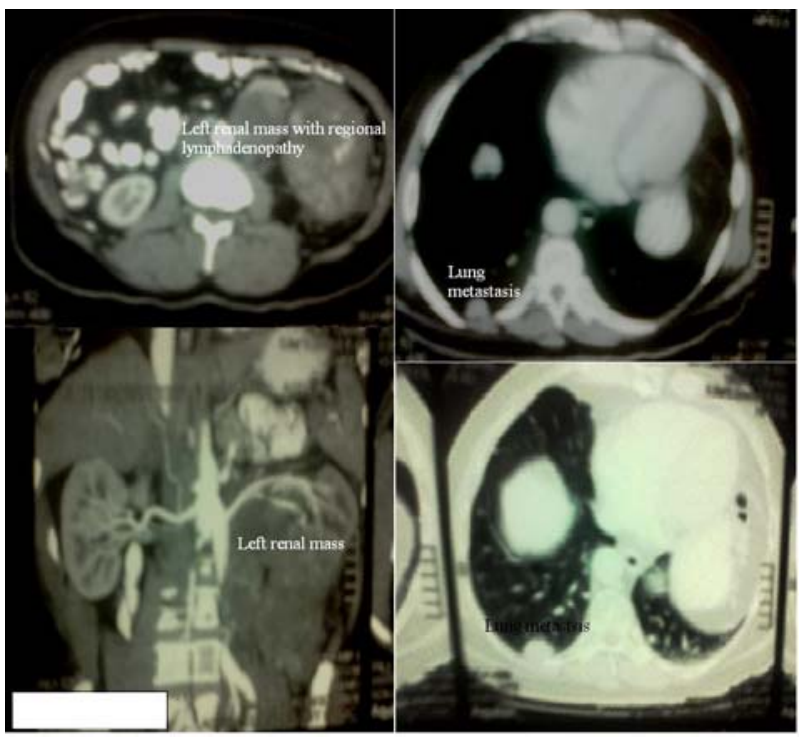

Figure 1 CT chest showed multiple pulmonary metastases

Urology team did debulking nephrectomy and metastasectomy of right lung nodule. The final pathologic findings of renal mass and pulmonary nodule consistent with clear cell type renal cell carcinoma. Primary tumor was infiltrating through Gerota's fascia and regional lymph nodes were also involved by renal cell carcinoma. TNM stage was made as pT3N1M1. Four week after surgery, he was started on sunitinib $50 \mathrm{mg}$ daily. Following 8 weeks of sunitinib, patient experienced recurrent epistaxis refractory to conventional treatment measures, prompting his presentation to emergency department. At that time, Physical examination was unremarkable for petechiae and diffuses ecchymoses, however some pupuric lesions were on the extremities and no splenomegaly was present. Complete blood count (CBC) showed platelet count was $40 \times 10^{9}$ per liter. His bleeding was stabilized after nasal packing and 10 units of platelets were transfused and patient was admitted for further management. On second day of platelet transfusion, the platelets further reduced to $15 \times 10^{9}$ per liter, however hemoglobin and white blood cell count were within normal limits indicating a refractory response to platelet transfusion. Peripheral blood smear showed thrombocytopenia and platelet volume was $20 \mathrm{fL}$ (normal range: 5-15 fL), with no evidence of schistocytosis or spherocytosis. However renal function tests, liver function tests and coagulation profile screen (international normalized ratio, prothrombin time, partial thromboplastin time) were within normal limits.

Differential diagnosis was made as sunitinib induced immune thrombocytopenic purpura. The sunitinib was stopped and he was treated with intravenous immunoglobulin (IVIG) at $65 \mathrm{~g}(1 \mathrm{~g} / \mathrm{kg})$ over 2 days and intravenous tranexamic acid. His platelet count rapidly improved to $100 \times 10^{9} / \mathrm{L}$ on day 5 of IVIG and returned to his normal baseline of $230 \times 10^{9} / \mathrm{L}$ after 2 weeks. Full recovery of platelets after withholding of sunitinib and IVIG support confirmed the diagnosis of 
sunitinib induced thrombocytopenia. Following his recovery of platelets, he was started on everolimus (Afinitor ${ }^{\circledR}$, Novartis, Switzerland) oral $10 \mathrm{mg}$ daily with no recurrent thrombocytopenia.

\section{DISCUSSION}

The discovery of isolated thrombocytopenia in a patient who is taking several medications presents a challenging clinical problem. The important diagnostic issue is to distinguish between DIIT and idiopathic thrombocytopenic purpura (ITP) because the latter diagnosis requires the exclusion of other causes of thrombocytopenia. ${ }^{6}$ Therefore; the clinician must determine whether one of the patient's medications may be the cause of the thrombocytopenia. Laboratory confirmation of DIIT is not possible because tests for drug-dependent antiplatelet antibodies are not available in routine. DIIT is associated commonly with various medications; quinidine, quinine, rifampin, digoxin, heparin, interferon alpha, and tamoxifen. ${ }^{7}$ DIIT is thought to be a result of antibody production in the presence of a sensitizing drug, with the antibodies targeting epitopes on the platelet surface, subsequently leading to clearance of the antibody-coated platelets by the mononuclear phagocytic system. ${ }^{8}$

Sunitinib has been documented to result in thrombocytopenia, with the causation attributed mainly to myelosuppression. Motzer, et $a l^{2}$ reported some grade of thrombocytopenia in 65 of 375 patients randomized to sunitinib 50 mg treatment; with 8 of the $65(12 \%)$ having grade 3 thrombocytopenia. Only one case of DIIT secondary to sunitinib has been reported $^{7}$ and one case microangiopathy induced thrombocytopenia in sunitinib receiving patient has been reported. ${ }^{9}$

In conclusion, sunitinib induced DIIT in our patient suggests that sunitinib and other multi-targeted tyrosine kinase inhibitors (TKIs) the oncologists must have a high index of suspicion for potential DIIT in patients with mRCC receiving these TKIs and that case the drug can safely be withdrawn.

Conflicting interest: Authors have neither potential conflict of interest nor received any grants for this case report. Written permission was taken from the patient for publication of the case report.

\section{REFERENCES}

1. Mendel DB, Laird AD, Xin X, Louie SG, Christensen JG, Li G, et al. In vivo antitumor activity of SU11248, a novel tyrosine kinase inhibitor targeting vascular endothelial growth factor and platelet-derived growth factor receptors: determination of a pharmacokinetic/pharmacodynamic relationship. Clin Cancer Res 2003;9:327-337. PMID:12538485

2. Motzer RJ, Hutson TE, Tomczak P, Michaelson MD, Bukowski RM, Rixe O, et al. Sunitinib versus interferon alfa in metastatic renal-cell carcinoma. N Engl J Med 2007 ;356:115-124. PMid:17215529. http://dx.doi.org/10.1056/NEJMoa065044

3. Goodman VL, Rock EP, Dagher R, Ramchandani RP, Abraham S, Gobburu JV, et al. Approval summary: sunitinib for the treatment of imatinib refractory or intolerant gastrointestinal stromal tumors and advanced renal cell carcinoma. Clin Cancer Res 2007;13:1367-1373. PMid:17332278 http://dx.doi.org/10.1158/1078-0432.CCR-06-2328

4. Kollmannsberger C, Bjarnason G, Burnett P, Creel P, Davis M, Dawson N, et al. Sunitinib in metastatic renal cell carcinoma: recommendations for management of noncardiovascular toxicities. Oncologist 2011;16:543-553.

PMid:21490127 http://dx.doi.org/10.1634/theoncologist.2010-0263

5. Trinkaus M, Trudeau M, Callum J. Drug-induced immune thrombocytopenic purpura secondary to sunitinib. Curr Oncol 2008;15:152-154. PMC2442762

6. George JN, Woolf SH, Raskob GE, Wasser JS, Aledort LM, Ballem PJ, et al. Idiopathic thrombocytopenic purpura: a practice guideline developed by explicit methods for the American Society of Hematology. Blood 1996; 88:3-40. PMID:8704187

7. George JN, Raskob GE, Shah SR, Rizvi MA, Hamilton SA, Osborne S, et al. Drug-induced thrombocytopenia: a systematic review of published case reports. Ann Intern Med 1998;129:886-890.

8. $\quad$ Aster RH, Bougie DW. Drug-induced immune thrombocytopenia. N Engl J Med 2007;357:580-587. PMID:9867731

9. Kapiteijn E, Brand A, Kroep J, Gelderblom H. Sunitinib induced hypertension, thrombotic microangiopathy and reversible posterior leukencephalopathy syndrome. Ann Oncol 2007; 18:1745-1747. http://dx.doi.org/10.1093/annonc/mdm454 